\title{
Modified Method for Propagation of Rift Valley Fever Virus
}

Taradi A. S. and K. E. Z. Hassan.

Veterinary Serum and Vaccine Research Institute, Abbassia, Cairo, Egypt.

\begin{abstract}
7 rials for propagation of RVFV on Vero cells using different MOI $10.1,0.01 \& 0.001$ and different concentrations of trypsin (25\& $50 \mu \mathrm{g} / \mathrm{ml})$. The result indicated that high titer of RVFV $\left(8.0 \log _{10}\right.$ $\mathrm{TCID}_{50} / \mathrm{ml}$ in Vero cells, $7.5 \log _{10} \mathrm{MIPLD}_{50} / \mathrm{ml}$ in adult mice and 7.7 $\log _{10} \mathrm{MICLD}_{50} / \mathrm{ml}$ in baby mice) was obtained with MOI 0.001 using $50 \mu \mathrm{g} / \mathrm{ml}$ of trypsin after $24 \mathrm{hrs}$ post inoculation. Inoculation of freshly subcultured Vero cells as other method lead to obtaining high virus titer $\left(8.5 \log _{10} \mathrm{TCID}_{50} / \mathrm{ml}\right.$ in Vero cells, $7.6 \log _{10} \mathrm{MIPLD}_{50} / \mathrm{ml}$ in adult mice and $8.2 \log _{10} \mathrm{MICLD}_{50} / \mathrm{ml}$ in baby mice) after 48 hours with MOI 0.0001 . While using subculture of monolayer Vero cells 24 hours previously infected with RVFV, it was obtained high titer (8.0 $\log _{10}$ TCID $_{50} / \mathrm{ml}$ in Vero cells, $7.4 \log _{10}$ MIPLD $_{50} / \mathrm{ml}$ in adult mice and $7.9 \log _{10} \mathrm{MICLD}_{50} / \mathrm{ml}$ in baby mice) with MOI 0.001 as well as a triple amount of virus yielded than the traditional method. Different batches of inactivated RVFV vaccine were prepared from the harvested virus which was identified as RVFV using AGPT. Quality control tests were applied proved that all vaccine batches were sterile, safe and potent. It is concluded that modified methods could increase RVFV production with high titer as well as saving time, saving materials used in virus production include quantity of inoculums.
\end{abstract}

Keywords: Rift valley, RVFV, Vero cells, Vaccine.

Vero=African green monkey kidney. RVFV= Rift Valley Fever virus. MOI $=$ multiplicity of infection. TCID $_{50}=$ tissue culture infective dose fifty. MIPLD ${ }_{50}=$ mice intraproteneal lethal dose fifty. MICLD $_{50}=$ mice intracerecberal lethal dose fifty. AGPT= Agar Gel Precipitation test.

Rift Valley fever virus (RVFV) is a bunyavirus endemic to Africa and the Arabian Peninsula that infects humans and livestock Mirabela et al. (2012). RVF is a peracute or acute zoonotic disease of domestic ruminants in Africa. The disease is most severe in sheep, goats and cattle, in which it produces abortions in pregnant animals and a high mortality rate in the newborn. RVF virus consists of a single serotype of a bunyavirus of the genus Phlebovirus and has morphological and physicochemical properties typical of bunya viruses. Primary isolations of the virus are usually made on cell cultures of various types, such as (Vero) cells, baby hamster kidney cells (BHK), chicken embryo reticulum (CER), or primary cells of sheep or cattle origin. The cultures are observed microscopically for 5-6 days. RVF virus induces a cytopathic effect (CPE) 
characterized by slight rounding of cells followed by destruction of the whole cell sheet within 12-24 hours. OIE, (2008).

Ellis et al. (1988) reported that RVFV grown in Vero cell cultures has completed replication cycle within 13 hours. The first signs are the appearance of intranuclear fibrillar rods, followed by aggregations of precursor viral material in host cell cytoplasm and viral nucleocapsids budding into vacuoles associated with the Golgi apparatus.

Trypsin is commonly used in Madin-Darby canine kidney (MDCK) cell culture-based influenza vaccine production to facilitate virus infection by proteolytic activation of viral haemagglutinin, which enables multi-cycle replication. Overall, addition of trypsin provided optimal conditions for high yield vaccine production in MDCK cells by two means. On the one hand, proteolytic degradation of IFN keeps cellular defence at a low level. On the other hand, enhanced virus spreading enables viruses to replicate before the cellular response becomes fully activated. (Seitz, et al., 2012).

In tissue culture laboratories, researchers use purified trypsin to release cells into suspension from monolayers growing on the interior surfaces of culture vessels Worthington Biochemical Corporation (2013).

If trypsin is allowed to stay in contact with the cells for too long a time, cell viability will reduce. Tissue culture media contains Calcium and Magnesium ions, foetal calf serum contains proteins that are trypsin inhibitors. Both $\mathrm{Mg}^{2+} / \mathrm{Ca}^{2+}$ inhibit trypsin, Protocol on line (2006).

Aim of this work to obtain high RVFV titer as well as increasing of virus yield for vaccine production with lower inoculum used.

\section{Material and Methods}

\section{Animals}

Lambs

Five lambs of 5-10 days old, 4 lambs were used for safety test of different prepared RVF vaccine batches and 1 lamb kept as negative control.

\section{Mice (Swiss albino mice)}

Adult mice 21-28 days old were used for titration of RVFV and potency of prepared inactivated vaccine batches. Baby mice 3-5 days old were used for titration of RVFV and safety of the prepared inactivated virus.

Virus

RVF virus ZH-501 with a titer of $7.5 \log _{10} \mathrm{TCID}_{50} / \mathrm{ml}$ was kindly supplied by RVF Department, Abbasia, Cairo. 
African green monkey kidney (Vero) cells

It was kindly supplied and propagated using growth minimum essential media by RVF Department, Abbasia, Cairo. It was used for virus propagation and titration.

\section{Trypsin solution}

$1 \%$ Trypsin solution was prepared, sterilized by filtration and kept at $-20^{\circ} \mathrm{C}$. Before use, it should be diluted in Hank's balanced salt solution get a final concentration of $0.25 \%$.

\section{Trypan blue staining solution}

Cell suspension was diluted 1:10 in sterile phosphate buffer saline (PBS), 100 $\mu 1$ cell suspension was mixed with an equal volume of $0.4 \%$ Trypan Blue stain, then Incubated 3-5 minutes at room temperature. Load a hemacytometer and count viable cells (viable cells are colorless and dead cells are blue).

\section{Effect of trypsin on Vero cells}

Different concentrations of trypsin $(25,50,100 \& 125 \mu \mathrm{g} / \mathrm{ml})$ were added to different flasks contains monolayer Vero cells and incubated for 10, $20 \& 30$ minutes at $37^{\circ} \mathrm{C}$. The viability of the cells tested microscopically using trypan blue to detect effect of trypsin.

\section{Experimental design of virus inoculation Inoculation of monolayer Vero cells treated with trypsin}

Monolayer Vero cells flasks were treated with different dose of trypsin (25 \& $50 \mu \mathrm{g} / \mathrm{ml}$ for each flask) for 10 minutes then inoculated with different MOI $(0.1$, $0.01 \& 0.001)$ of RVFV. The virus was collected 24 hours post-inoculation and titrated, in comparison with control (traditional method of RVFV inoculation of monolayer cells using $0.01 \mathrm{MOI}$ ).

\section{Inoculation of freshly subcultured Vero cells}

Vero cells freshly subcultured inoculated with different MOI $(0.1,0.01$, $0.001 \& 0.0001)$ and collected at different times post - inoculation $(24,48$ and 72 hours) for virus titration, in comparison with control (traditional method of RVFV inoculation of monolayer cells using 0.01 MOI).

Subculture of 24 hours previously Inoculated monolayer Vero cells

Vero cells inoculated with different MOI $(0.1,0.01,0.001 \& 0.0001)$ of RVFV and after 24 hours supernatant fluid ( $100 \mathrm{ml} /$ Roux bottle) collected and the infected cells subcultured into 2 Roux bottles $(200 \mathrm{ml}$ total). After 24 hours the bottles kept at $-20^{\circ} \mathrm{C}$. The collected virus was titrated, in comparison with control (traditional method of RVFV inoculation of monolayer cells using $0.01 \mathrm{MOI}$ ).

\section{Titration of RVF virus harvest}

Titration of the harvest were done on tissue culture and in mice (I/P for adult and I/C for baby), according to (Taha, 1982) and calculation using formula of (Reed and Muench, 1938). 
Agar Gel Precipitation test (AGPT)

It was applied for detection of RVFV identity according to (Taradi 2003).

Preparation of the vaccine

RVF ZH-501 was inactivated by binary ethyleneimine according to Eman (1995).

Evaluation of the vaccine

Sterility, Safety and Potency testes were performed according to OIE, (2008).

\section{Results and Discussion}

Rift Valley fever (RVF) is a viral zoonosis that primarily affects animals but also has the capacity to infect humans. Infection can cause severe disease in both animals and humans. The disease also results in significant economic losses due to death and abortion among RVF-infected livestock. WHO, (2012). Control of RVF disease in Egypt depends mainly on vaccination of susceptible animals. Therefore inactivated RVF vaccine was prepared locally using RVFV with MOI 0.1 to 0.01 according to El-Nimr (1980). The time of peak titer was dependent on MOI and initial cell concentration (Walker et al., 1969).

In a tissue culture lab, trypsin is used to re-suspend cells adherent to the cell culture flasks wall during the process of harvesting cells. Some cell types have a tendency to "stick" - or adhere - to the sides and bottom of a flask when cultivated in vitro. So that the cells can be suspended in fresh solution and transferred to fresh flasks, Wikimedia Foundation, Inc. (2013).

Table 1 studied the effect of trypsin on Vero cells at different times and different concentrations, the result revealed that trypsin at concentrations of $25 \&$ $50 \mu \mathrm{g} / \mathrm{ml}$ were safe and viability of the cell was $100 \%$ within $10,20 \& 30 \mathrm{~min}$. using trypan blue.

TABLE 1. Effect of trypsin on Vero cells.

\begin{tabular}{|c|l|l|l|l|}
\hline \multirow{2}{*}{ Time / min } & \multicolumn{4}{|c|}{ Trypsin concentration / ml } \\
\cline { 2 - 5 } & $\mathbf{2 5} \boldsymbol{\mu g}$ & $\mathbf{5 0} \boldsymbol{\mu g}$ & $\mathbf{1 0 0} \boldsymbol{\mu g}$ & $\mathbf{1 2 5} \boldsymbol{\mu g}$ \\
\hline 10 & $100 \% *$ & $100 \%$ & $100 \%$ & $100 \%$ \\
\hline 20 & $100 \%$ & $100 \%$ & $80 \%$ & $70 \%$ \\
\hline 30 & $100 \%$ & $100 \%$ & $50 \%$ & $40 \%$ \\
\hline
\end{tabular}

Table 2 studied the propagation of RVFV with different MOI for 24 hours on Vero cells treated for 10 minutes with concentration of 25 and $50 \mu \mathrm{g} / \mathrm{ml}$ of trypsin before inoculation. The virus titers $\left(8.0 \log _{10} \mathrm{TCID}_{50} / \mathrm{ml}\right.$ in Vero cells, $7.5 \log _{10}$ MIPLD $D_{50} / \mathrm{ml}$ in adult mice and $7.7 \log _{10} \mathrm{MICLD}_{50} / \mathrm{ml}$ in baby mice) were obtained

Egypt. J. Vet. Sci. Vol. 45-46 (2014 - 2015) 
with MOI 0.001 using $50 \mu \mathrm{g} / \mathrm{ml}$ of trypsin. Trypsin is used to cleave proteins bonding the cultured cells to the tissue culture flasks Wikimedia Foundation, Inc. (2013). These results may be attributed to the effect of trypsin on increasing the exposure surface of cells which increase the tendency of the virus to be adsorbed.

TABLE 2. Titration of RVFV after 24 hours propagated on Vero cells treated with trypsin.

\begin{tabular}{|c|c|c|c|c|c|c|}
\hline \multirow{4}{*}{$\begin{array}{c}\text { MOI/ } \\
\text { cell }\end{array}$} & \multicolumn{6}{|c|}{ Trypsin concentration / ml } \\
\hline & \multicolumn{3}{|c|}{$25 \mu \mathrm{g}$} & \multicolumn{3}{|c|}{$50 \mu \mathrm{g}$} \\
\hline & \multirow{2}{*}{$\begin{array}{c}\text { Tissue } \\
\text { culture } \\
\log _{10} \mathrm{TCI} \\
\mathrm{D}_{50} / \mathrm{ml} \\
\end{array}$} & \multicolumn{2}{|c|}{ Mice } & \multirow{2}{*}{\begin{tabular}{|c|} 
Tissue \\
culture \\
$\log _{10} \mathrm{TCID}$ \\
$50 / \mathrm{ml}$ \\
\end{tabular}} & \multicolumn{2}{|c|}{ Mice } \\
\hline & & $\begin{array}{c}\text { Log } \\
{ }_{10} \mathrm{MIPLD}_{50}\end{array}$ & $\begin{array}{c}\log \\
{ }_{10} \mathrm{MICLD}_{50}\end{array}$ & & $\begin{array}{c}\log \\
{ }_{10} \mathrm{MIPLD}_{50}\end{array}$ & \begin{tabular}{|c|}
$\log$ \\
${ }_{10} \mathrm{MICLD}_{50}$
\end{tabular} \\
\hline 0.1 & 7.0 & 6.5 & 6.8 & 7.2 & 6.7 & 6.9 \\
\hline 0.01 & 7.2 & 6.7 & 6.9 & 7.5 & 7.0 & 7.2 \\
\hline 0.001 & 7.5 & 7.0 & 7.2 & $8.0 *$ & 7.5 & 7.7 \\
\hline control & 6.5 & 5.5 & 6.0 & 6.5 & 5.5 & 6.0 \\
\hline
\end{tabular}

$=$ batch I of vaccine.

Table 3 explain titration of RVF virus propagated on freshly subcultured Vero cells inoculated with different MOI and collected at different times post-inoculation (24, 48 and 72 hours). Highest titers of RVFV were obtained after 48 hours, it was $8.5 \log _{10} \mathrm{TCID}_{50} / \mathrm{ml}$ on Vero cells, $7.6 \log _{10} \mathrm{MIPLD}_{50} / \mathrm{ml}$ in adult mice and $8.2 \log _{10}$ $\mathrm{MICLD}_{50} / \mathrm{ml}$ in baby mice with MOI 0.0001 , while the titers were lower at $24 \& 72$ hours. The result indicated that, the highest virus titer reached by using lower MOI with freshly subcultured Vero cells, this result was agreed with Taradi et al. (2009) whom found that the highest RVF virus titer $\left(8.0 \log _{10} \mathrm{TCID}_{50} / \mathrm{ml}\right)$ was obtained at $48 \mathrm{hrs}$ in cell free virus of the infected tissue culture cells.

TABLE 3. Titration of RVFV propagated on freshly subcultured Vero cells.

\begin{tabular}{|c|c|c|c|c|c|c|c|c|c|}
\hline \multirow{4}{*}{$\begin{array}{c}\text { MOI / } \\
\text { cell }\end{array}$} & \multicolumn{9}{|c|}{ Time post - inoculation } \\
\hline & \multicolumn{3}{|c|}{24 hours } & \multicolumn{3}{|c|}{48 hours } & \multicolumn{3}{|c|}{72 hours } \\
\hline & \multirow{2}{*}{\begin{tabular}{|c|} 
TC \\
$\log _{10}$ \\
TCID \\
${ }_{50} / \mathrm{ml}$ \\
\end{tabular}} & \multicolumn{2}{|c|}{ Mice } & \multirow{2}{*}{$\begin{array}{c}\text { TC } \\
\log _{10} \\
\text { TCID }_{50} / \\
\text { ml }\end{array}$} & \multicolumn{2}{|c|}{ Mice } & \multirow{2}{*}{$\begin{array}{c}\text { TC } \\
\log _{10} \\
\operatorname{TCID}_{50} / \\
\text { ml }\end{array}$} & \multicolumn{2}{|c|}{ Mice } \\
\hline & & $\begin{array}{c}\log _{10} \\
\text { MIPL } \\
D_{50}\end{array}$ & $\begin{array}{c}\log _{10} \\
\text { MICL } \\
D_{50}\end{array}$ & & $\begin{array}{c}\log _{10} \\
\text { MIPL } \\
D_{50}\end{array}$ & $\begin{array}{c}\log _{10} \\
\text { MICL } \\
D_{50}\end{array}$ & & $\begin{array}{c}\log _{10} \\
\text { MIPL } \\
D_{50}\end{array}$ & $\begin{array}{c}\log _{10} \\
\text { MICL } \\
D_{50}\end{array}$ \\
\hline 0.1 & 6.0 & 5.3 & 5.8 & 6.7 & 6.0 & 6.5 & 5.2 & 4.9 & 5.1 \\
\hline 0.01 & 6.1 & 5.5 & 5.9 & 7.4 & 6.9 & 7.2 & 5.1 & 4.7 & 4.9 \\
\hline 0.001 & 6.5 & 5.6 & 6.1 & 8.0 & 7.2 & 7.9 & 5.0 & 4.5 & 4.9 \\
\hline 0.0001 & 6.0 & 5.3 & 5.8 & $8.5^{*}$ & 7.6 & 8.2 & 5.2 & 4.8 & 5.1 \\
\hline control & 6.5 & 5.5 & 6.0 & 7.5 & 7.1 & 7.3 & 5.0 & 4.5 & 4.7 \\
\hline
\end{tabular}

$*$ = batch II of vaccine.

Table 4 declared result of titration of RVFV of supernatant fluid $(100 \mathrm{ml})$ collected from 24 hours of previously infected Vero cells, the titers were 7.5 $\log _{10} \mathrm{TCID}_{50} / \mathrm{ml}$ on Vero cells, $6.9 \log _{10} \mathrm{MIPLD}_{50} / \mathrm{ml}$ in adult mice and 7.3 $\log _{10} \mathrm{MICLD}_{50} / \mathrm{ml}$ in baby mice with MOI $(0.001)$ this result was agreed with 
Taha (1982) who found that, the highest RVF virus titer $\left(7.3 \log _{10} \mathrm{TCID}_{50} / \mathrm{ml}\right)$ was obtained at 28 hours in cell-free virus of infected tissue culture cells, while the highest titers of harvested RVFV were obtained after subculture of infected Vero cells $(200 \mathrm{ml})$, it were $8.5 \log _{10} \mathrm{TCID}_{50} / \mathrm{ml}$ on Vero cells, $7.9 \log _{10}$ MIPLD $_{50} / \mathrm{ml}$ in adult mice and $8.3 \log _{10}$ MICLD $_{50} / \mathrm{ml}$ in baby mice with MOI (0.001). The mean titer of collected virus $(300 \mathrm{ml})$ was $8.0 \log _{10} \mathrm{TCID}_{50} / \mathrm{ml}$ on Vero cells, $7.4 \log _{10}$ MIPLD $_{50} / \mathrm{ml}$ in adult mice and $7.9 \log _{10} \mathrm{MICLD}_{50} / \mathrm{ml}$ in baby mice. These results proved that we can obtain high titer of RVFV as well as increased volume of harvest virus using low quantity of inoculums.

TABLE 4. Titration of RVFV 24 hours previously infected Vero cells before and after subculture.

\begin{tabular}{|c|c|c|c|c|c|c|c|c|c|c|}
\hline \multirow{3}{*}{$\begin{array}{c}\text { MOI / } \\
\text { cell }\end{array}$} & \multicolumn{3}{|c|}{$\begin{array}{c}\text { Titer of RVFV before } \\
\text { subculture }\end{array}$} & \multicolumn{3}{|c|}{$\begin{array}{c}\text { Titer of RVFV after } \\
\text { subculture }\end{array}$} & \multirow{3}{*}{$\begin{array}{c}\text { Amount } \\
\text { of virus } \\
\text { yield /ml }\end{array}$} & \multicolumn{3}{|c|}{ Mean titer } \\
\hline & \multirow{2}{*}{\begin{tabular}{|c|} 
TC \\
$\log _{10}$ \\
TCID \\
${ }_{0} / \mathrm{ml}$
\end{tabular}} & \multicolumn{2}{|c|}{ Mice } & \multirow{2}{*}{$\begin{array}{c}\text { TC } \\
\log _{10} \\
\operatorname{TCID}_{50} / \\
\text { ml }\end{array}$} & \multicolumn{2}{|c|}{ Mice } & & \multirow{2}{*}{$\begin{array}{c}\mathrm{TC} \\
\log _{10} \\
\text { TCID }_{5} \\
{ }_{0} / \mathrm{ml}\end{array}$} & \multicolumn{2}{|c|}{ Mice } \\
\hline & & $\begin{array}{c}\log _{10} \\
\text { MIPL } \\
D_{50}\end{array}$ & $\begin{array}{c}\log _{10} \\
\text { MICL } \\
\text { D }_{50}\end{array}$ & & $\begin{array}{c}\log _{10} \\
\text { MIPL } \\
D_{50}\end{array}$ & $\begin{array}{l}\log _{10} \\
\text { MIC } \\
\text { LD }_{50}\end{array}$ & & & $\begin{array}{c}\log _{10} \\
\text { MIPL } \\
D_{50} \\
\end{array}$ & $\begin{array}{c}\log _{10} \\
\text { MICL } \\
D_{50}\end{array}$ \\
\hline 0.1 & 6.0 & 5.4 & 5.9 & 3.3 & 2.9 & 3.2 & 300 & 4.7 & 4.2 & 4.5 \\
\hline 0.01 & 6.9 & 6.4 & 6.7 & 8.0 & 7.4 & 7.8 & 300 & 7.5 & 6.9 & 7.3 \\
\hline 0.001 & 7.5 & 6.9 & 7.3 & $8.5^{*}$ & 7.9 & 8.3 & 300 & 8.0 & 7.4 & 7.9 \\
\hline 0.0001 & 6.2 & 5.6 & 6.0 & 7.7 & 7.1 & 7.5 & 300 & 7.0 & 6.8 & 7.0 \\
\hline control & ND & ND & ND & 7.5 & 7.1 & 7.3 & 100 & ND & ND & ND \\
\hline
\end{tabular}

AGPT as in Table 5 was applied on the collected virus using hyper-immune serum against RVFV which cleared that the collected virus was identified as RVFV this result was agreed with Taradi (2003). The prepared batches of the inactivated RVFV vaccine were evaluated according OIE (2008) in comparison the traditional vaccine, the batches were sterile, safe (neither deaths in baby mice and nor elevation of body temperature of inoculated lambs) and potent (ED $\mathrm{E}_{50}$ $0.002,0.003,0.001$ and 0.002 for batch I, II, III and traditional vaccine respectively). It is concluded that modified methods could obtain high titer of RVFV as well as saving time and increased volume of propagated virus using low quantity of inoculums.

TABLE 5. Evaluation of different batches of inactivated RVF vaccine.

\begin{tabular}{|c|c|c|c|c|c|}
\hline \multirow{2}{*}{$\begin{array}{l}\text { Vaccine } \\
\text { batches }\end{array}$} & \multirow{2}{*}{ AGPT } & \multirow{2}{*}{ Sterility } & \multicolumn{2}{|c|}{ Safety } & \multirow{2}{*}{$\begin{array}{c}\text { Potency } \\
\text { ED }_{50} \text { in mice }\end{array}$} \\
\hline & & & In lamb & In mice & \\
\hline I & +ve & Sterile & Safe* & Safe** & 0.002 \\
\hline II & +ve & Sterile & Safe & Safe & 0.003 \\
\hline III & +ve & Sterile & Safe & Safe & 0.001 \\
\hline $\begin{array}{c}\text { Traditional } \\
\text { vaccine }\end{array}$ & +ve & Sterile & Safe & Safe & 0.002 \\
\hline
\end{tabular}

Egypt. J. Vet. Sci. Vol. 45-46 (2014 - 2015) 


\section{References}

Ellis, D.S., Shirodaria, P.V., Fleming, E. and Simpson, D.I. (1988) Morphology and development of RVF virus in Vero -cell cultures. J. Med. Virology, 24 (2), 161-173.

El-Nimr, M.M. (1980) Studies on the inactivated vaccine against Rift Valley Fever. Ph.D. Thesis, (Microbiology) Fac. Vet. Med. Assuit Univ. Egypt.

Eman, M.S. (1995) Studies on Rift Valley Fever vaccine inactivated with binary. Ph.D. Thesis, Vet. Sc., Fac. Vet. Med., Cairo Univ., Egypt.

Mirabela, R., Richard B., Michael R. H., Stanley J. W., Stefan B., Willy W. and Alexander N. F. (2012) An assembly model of rift valley fever virus. Front Microbiol., 3 , 254-259.

OIE Terrestrial Manual ( 2008) Rift Valley fever Chapter 2.1.14.

Protocol on Line (2006) Why EDTA in trypsin?

Reed, L.J. and Muench, H. (1938) A simple method for estimating 50 percent end point. Am. J. Hyg., 27 , $493-497$

Seitz, C., Isken, B., Heynisch, B., Rettkowski, M., Frensing, T. and Reichl, U. (2012) Trypsin promotes efficient influenza vaccine production in MDCK cells by interfering with the antiviral host response. Appl. Microbiol. Biotechnol., Jan, 93 (2), 601-11.

Taha, M.M. (1982) Studies on inactivated vaccine of Rift Valley Fever V. Ph.D. Thesis, (Microbiology), Fac. Vet. Med., Cairo Univ.

Taradi, A.S., Hassan, K.E.Z., Eman, M.S., Taha, M.M., Gihan, K.M. and El- Helw, H.A. (2009) Differentiation between the antigenicity and protein structure of both attenuated (smithburn strain) and virulent (ZH501 strain) Rift Valley Fever virus. Alex. J. Vet. Med. 28 (1), 331-338.

Taradi, A.S. (2003) Production of some diagnostic reagent for Rift valley fever. Ph.D. Thesis, Fac. Vet. Med., Cairo Univ., Egypt.

Walker, J.S, Carter, R.C, Klein, F, Snowden, S.E and Lincoln, R.E. (1969) Evaluation of factors related to growth of Rift Valley fever virus in suspended cell cultures. Appl. Microbiol., 17 (5), 658-64.

WHO (2012) Rift Valley fever. Fact sheet N²07

Wikimedia Foundation, Inc. (2013) Trypsin

Worthington Biochemical Corporation (2013) Dissociating Enzymes: Trypsin Worthington Tissue Dissociation Guide. 730 Vassar Ave., Lakewood, NJ 08701.

(Received 20/ 8/2014;

accepted 1/ 10/2015)

Egypt. J. Vet. Sci. Vol. 45-46 (2014 - 2015) 


\section{طريقة مطورة لتكاثز فيروس حمى الوادي المتصدع \\ تراضى عبد الفتاح سبا و كريم الدين زكي حسن \\ معهد بحوث الأمصال و اللقاحات البيطرية ـ العباسية ـ القاهرة ـ مصر.}

تم دراسة تكاثر فيروس حمى الو ادي المتصدع على خلايا الزرع النسيجي الفيرو

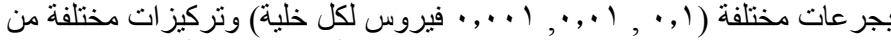

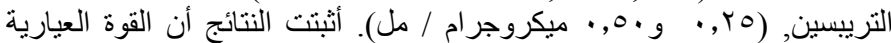

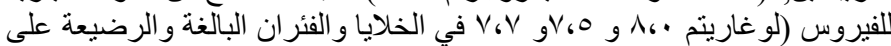

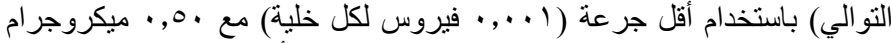

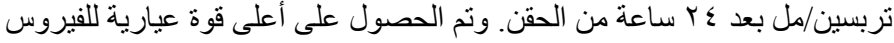

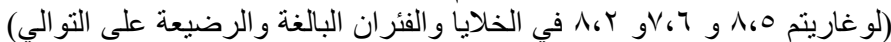

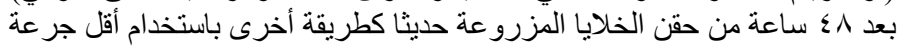

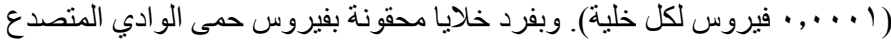

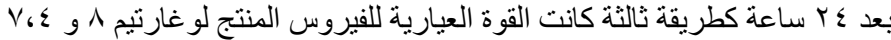

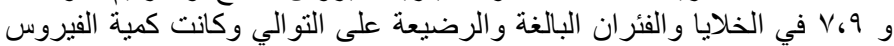

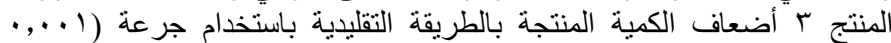

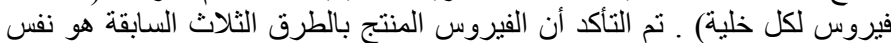

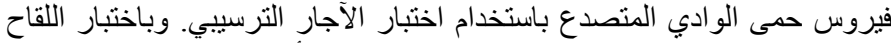

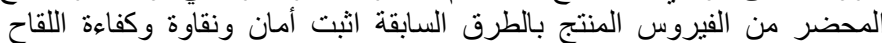

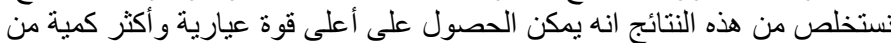

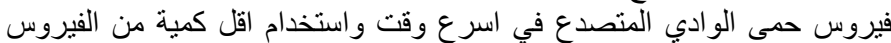

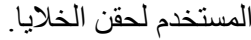

